\title{
Angioedema in Systemic Lupus Erythematosus (SLE) in Emergency Setting: A Case Report
}

\author{
Nur Mujaddidah Mochtar ${ }^{1}$, Ricky Indra Alfaray $^{2}$, Detty Irawaty ${ }^{3}$, Yelvi Levani* ${ }^{* 4}$ \\ ${ }^{1}$ Department of Anatomy-Histology, Faculty of Medicine, Muhammadiyah University of Surabaya \\ 2 Faculty of Medicine, Muhammadiyah University of Surabaya \\ ${ }^{3}$ Department of Internal Medicine of Siti Khodijah Sepanjang Hospital of Sidoarjo \\ ${ }^{4}$ Faculty of Medicine, Muhammadiyah University of Surabaya.
}

DATA OF ARTICLE:

Received: 31 Nov 2019

Reviewed: 10 Mar 2020

Revised: 09 Jun 2020

Accepted: $01 \mathrm{Jul} 2020$

\section{*CORRESPONDENCE: \\ yelvilevani@fk.um- \\ surabaya.ac.id}

DOI:

$10.18196 / \mathrm{mm} .200252$

TYPE OF ARTICLE:

Case Report

\begin{abstract}
Systemic Lupus Erythematosus (SLE) is an autoimmune disease that causes chronic inflammation with its characteristics of the autoantibody formation, attacks nuclear antigen. This disease may damage multisystem organs, its diagnoses, are barely implemented in the Emergency Department. However, cases of angioedema on SLE patient are quite uncommon not only in Indonesia but also globally. This article report an interesting case of 20 years old woman who came to the Emergency Department of Siti Khodijah Sepanjang Hospital with a swollen lips for three days. Both complaint and examination led to the diagnosis of SLE. However, because the incidence rate of angioedema on SLE is low, doctors tend to unconsider the appropriate diagnosis management and administration on this breathing problem caused by SLE.
\end{abstract}

Keywords: Systemic Lupus Erythematosus, angioedema, emergency

\begin{abstract}
Abstrak: Sistemic Lupus Eritematosus (SLE) adalah penyakit autoimun yang menyebabkan peradangan kronis dengan karakteristik pembentukan autoantibodi yang menyerang antigen. Penyakit ini dapat merusak organ multisistem, dan diagnosisnya hampir tidak diterapkan di Unit Gawat Darurat. Namun, kasus angioedema pada pasien SLE sangat jarang tidak hanya di Indonesia tetapi juga secara global. Artikel ini melaporkan kasus menarik dari wanita berusia 20 tahun yang datang ke Unit Gawat Darurat Rumah Sakit Siti Khodijah Sepanjang dengan keluhan bibir bengkak selama tiga hari. Keluhan dan pemeriksaan mengarah pada diagnosis SLE. Namun, karena tingkat kejadian angioedema pada SLE rendah, dokter cenderung tidak mempertimbangkan manajemen diagnosis yang tepat dan administrasi pada masalah pernapasan yang disebabkan oleh SLE ini.
\end{abstract}

Kata kunci: Sistemik Lupus Eritematosus, angioedema, gawat darurat

\section{INTRODUCTION}

Systemic Lupus Erythematosus (SLE) is an autoimmune disease that causes chronic inflammation with its characteristic of the autobody formation, attacks nuclear antigen. ${ }^{1}$ This disease may damage multisystem organs, its diagnoses, are barely implemented in Emergency Departments. ${ }^{2}$ The overall SLE prevalence in Asia Pacific is around 4.3-43.5 (per 100.000 populations). ${ }^{3}$ Meanwhile in
Indonesia, there are reportedly 1.250 .000 patients and most of the patients do not know that they suffer from SLE. On the other side, the fact shows that almost $50 \%$ of Indonesian doctors in primary care have insufficient understanding of SLE disease. 4

The emergency of SLE disease is, it may result in multisystem organs failure. In the cardiovascular system, the emergencies are stroke, cardiac tamponade, and myocardial infarction. In 
the respiration system, the emergencies are such as pulmonary edema, pulmonary hemorrhage, and respiration distress. ${ }^{5}$ In the other systems, kidney failure, cerebry and many other diseases may occur in multisystem organs. ${ }^{6}$

It is very essential for medical staff in Emergency Department, especially the doctors, to understand this because SLE patients have the risk to be treated in Emergency Department twice as risky as non-SLE patients ${ }^{7}$ and the mortality rate for SLE patients is five times higher than common population. ${ }^{8}$ The morbidity and mortality rates for SLE patients are also quite high. ${ }^{9}$ Angioedema clinics which are physically observable are the swellings on the face, especially on the eyes and lips. ${ }^{10}$ Angioedema can be a life-threatening condition for $15-33 \%$ SLE patients. ${ }^{11}$ There shall be systematic and comprehensive handling management to reduce the ratio of mortality and morbidity in SLE emergency cases. However, in Indonesia, there are no guidelines or journals that explain about its treatment. Hence, this article was written in order to explain the comprehensive management for angioedema treatment on SLE patients and it was adjusted with the emergency condition handling in Indonesian Emergency Departments as well as its implementation on a found case.

\section{CASES}

A 20-years old woman, unmarried, domiciled in Sidoarjo, came to the Emergency Department of Siti Khodijah Sepanjang Hospital, along with her family, on October 19, 2018, with a complaint of swollen lips for three days. This was the first time for the patient. The other complaints were that the eyes were swollen, no appetite due to sprue, a little bit coughing and sore throat, fever, the body was weak, limp, and pale. There were also red and itchy rashes on the face and upper limb for three months continuously. The patient complained that the red rashes on the cheek started to feel like a sunburn. The patient also complained that hair started to lose. Shortness of breath was denied.

Several denied multisystem organ disorders were such as disorders on musculoskeletal, such as swelling or pain on the muscles and joints; digestion system disorders such as dysphagia and constipation; disorders on kidney functions such as thicker or red-colored urine and swollen feet; disorders on neuro system such as memory disorder and convulsion; disorders on cardiovascular and pulmonary systems such as bleeding, pain on chest area and out of breath. Allergic history to foods, medicines, or any allergen was denied. Family medical history for similar diseases and atopic was also denied.

Physical examination on this patient showed that her body was generally in a weak condition, compos mentis consciousness, blood pressure at $110 / 70 \mathrm{mmHg}$, respiratory rate 24 times/minute without any additional breathing sound, oxygen saturation $94 \%$, pulse velocity 82 times/minute and temperature at $36,8^{\circ} \mathrm{C}$. From the examination on the local area, conjunctiva was pale and dermatological area around the face was found butterfly-shaped malar and discoid rashes at the cheeks and nose, half erythema plaques were hypopigmented, irregular shape, clear edge, white thin scale (squama) on top of it, crust and erosion. Multiple ulcers were found on lips and mouth area. There was no disorder on the thorax, abdomen, or limbs, such as swelling or pain on the joints. Laryngoscopy has not been done in this patient.

Supporting examinations that have been carried out at the emergency department are laboratory tests and chest X-rays. Laboratory results

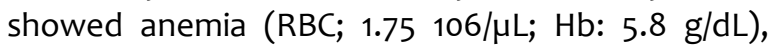
increased erythrocyte sedimentation rate (hour I: 150; Hour II: 155 mm/hour), leukopenia (1.03 106/ $\mu \mathrm{L}$ ). The chest X-ray examination was within normal limits.

The patient was treated with infusion of ringer lactate: dextrose 5\% 2:1 and nasal oxygen 2-3 liters/minute. The drug given was corticosteroids in the form of methylprednisolone $3 \times 125 \mathrm{mg}$, then observation of danger signs, such as asphyxia and improvement of complaints, especially swelling in the mouth and swollen eye. One hour after administration of the drug, the patient's condition gradually improved, seen from a physical examination that showed the good general condition, awareness was compos mentis, blood pressure at $115 / 70 \mathrm{mmHg}$, respiration rate was 20 times/minute, oxygen saturation was $98 \%$, pulse rate was 82 times/minute, and the temperature was $36.9^{\circ} \mathrm{C}$. Angioedema in patients seen from swollen lips gradually disappears.

Laboratory testing when the patient was in an inpatient setting shows a positive ANA and anti dsDNA examination. Skin biopsy examination is taken from erythematous spots in the sun-exposed area. Epidermal histopathological features hyfae, budding cells, and sunburn cells appear. Based on the anamnesis, physical examination and supporting examination, the working diagnosis is then made as systemic lupus erythematosus with LE cutaneous. The patient was treated cooperatively with the Internal Medicine Department of the Rheumatology and Tropical Infection Subdivision 
with a diagnosis of systemic lupus erythematosus. The patient agreed with her case being reported.

\section{DISCUSSION}

Angioedema is a condition of swelling of the subcutaneous or submucosal layer that occurs in the local area as a result of extravasation of fluid into the interstitial tissue. This can occur in parts of the body that have loose connective tissue such as the lips, periorbital, extremities, genitalia, and even the digestive tract and upper respiratory tract. ${ }^{12}$ This condition last up to several hours or days but normally does not exceed 72 hours. Angioedema is considered dangerous if it occurs in the upper respiratory tract and causes respiratory obstruction such as laryngeal edema and pharyngeal edema. Angioedema in SLE patients can be categorized as acquired angioedema (AAE) and hereditary angioedema (HAE). Cases of angioedema in SLE patients are a rare condition ${ }^{12}$. Comprehensive management of angioedema treatment of SLE patients in the emergency department requires a different approach to allergic patients because both have different pathophysiological mechanisms.

Based on the pathophysiology, angioedema is divided into two namely mast cell mediated and kinin mediated (Figure 1). ${ }^{13}$ Mast cell mediated is the most often found in angioedema. The clinical difference, can be found to differentiate the two is that in mast cell mediated, patients are often accompanied by urticaria, sneezing, and itching after exposure to certain allergens, whereas in kinin mediated, patients often do not feel it. At kinin mediated, the most common cause is acquired $\mathrm{C}_{1}$ esterase inhibitor protein ( $\mathrm{C} 1-\mathrm{INH})$ deficiency. These deficiencies, both quantitative and qualitative, can occur due to autoantibodies or increased catabolism in C1-INH. This form of angioedema is often found in autoimmune patients or in patients with lymphoproliferative disorder. ${ }^{13}$

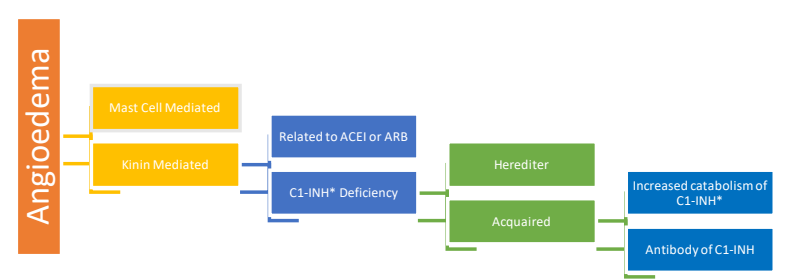

Figure 1. Division of Angioedema Pathophysiology ${ }^{13}$ ACEI: angiotensin converting enzyme inhibitor; ARB: angiotensin II receptor blocker; C1-INH: C1-esterase inhibitor protein.

*: Angioedema Pathophysiology related to SLE

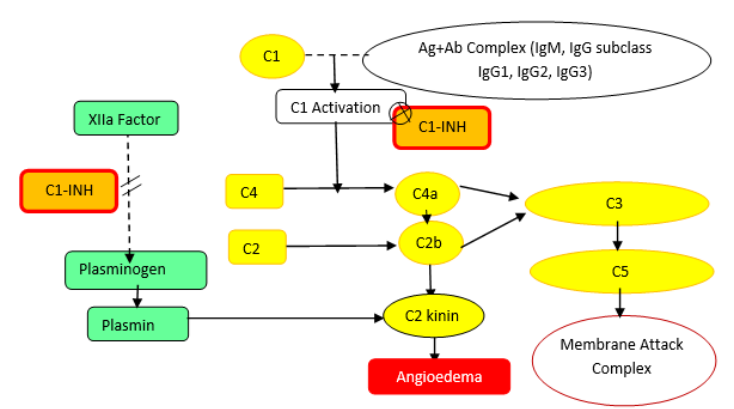

Figure 2. Angioedema Pathophysiology Due to C1-INH Deficiency $^{15}$

Angioedema in SLE is often found to be associated with classical pathway-mediated hypocomplementemia (low $\mathrm{C}_{3}$ and $\mathrm{C}_{4}$ ) and transient low C1-INH antigenic. Angioedema that causes transient low $\mathrm{C}_{1-\mathrm{INH}}$ antigenic or further called a $\mathrm{C}_{1}$ esterase inhibitor ( $\mathrm{C} 1-\mathrm{INH})$ deficiency can be a hereditary-autosomal dominant disease, it can be also called hereditary angioedema (HAE) or acquired disease (acquired-without family history) (Figure 1). Secondary allergic angioedema due to systemic SLE can also occur due to C1-INH deficiency, positive antinuclear antibodies, and hypocomplementemia. ${ }^{14}$ In secondary allergic angioedema, both clinical between mast cellmediated and kinin mediated can appear.

C1-INH is a potent inhibitor of the classical pathway for angioedema by inhibiting $\mathrm{C}_{1}$ activation and Plasmin activity (Figure 2). ${ }^{15} \mathrm{C}$-INH deficiency causes an increase in activity of the kinin mediated pathway. Activation of $\mathrm{C}_{1}$ is a response to AntigenAntibody Complex (IgM, IgG subclass IgG1, IgG2, $\left.\lg \mathrm{C}_{3}\right)$. Activation of $\mathrm{C}_{1}$ triggers $\mathrm{C}_{4}$ to divide into large fragments (C4b) and small fragments (C4a). C4a with $C_{2}$ b ultimately relates to $C_{2}$ kinin and plasmin which cause angioedema. On the other hand, small fragments of $\mathrm{C}_{4}$ ( $\left.\mathrm{C}_{4} \mathrm{a}\right)$, small fragments of C3 (C3a), and small fragments of C5 (C5a) are parts of complement that have anaphylatoxin activity. C5a itself is one of the most powerful inflammatory peptides. $\mathrm{C}_{5}$ a has strong neutrophil aggregation activity, strong neutrophil chemotaxis activity, and is a very good anaphylactin. ${ }^{16}$ C5a is capable of causing mast cell degranulation and histamine release which causes allergic manifestations. The end result of the overall complement host system is Membrane Attack Complex (MAC) or also called Terminal Complement Complex (TCC). ${ }^{17}$ The whole process is important to understand so that the doctor understands the clinical manifestations of SLE patients accompanied by angioedema with or without clinical allergies. 


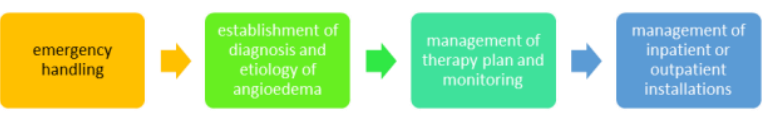

Figure 3. The sequence of comprehensive management processes for handling angioedema in patients with SLE in the Emergency Department

Comprehensive management of angioedema treatment for SLE patients in the emergency department begins with emergency handling, then establishment of diagnosis and etiology of angioedema, management of therapy plan and monitoring, as well as management of inpatient or outpatient installations (Figure 3). The thing to note is handling the initial emergency due to angioedema. In the event that it is not immediately treated, upper airway obstruction due to edema can cause the patient to die within a few minutes due to hypoxia. ${ }^{10}$ Airway problems can occur to both the upper and lower respiratory tracts. $^{18}$ Other than epiglottitis, laryngitis, vocal cord edema and necrotic tracheitis, angioedema can also occur on the upper respiratory tract. ${ }^{15}$ The angioedemas were not only found in the form of cutaneous edema on the face, but also on the larynx, genital area or even gastrointestinal area. ${ }^{10}$

In reported cases, the emergency condition that can be found in patients related to angioedema is the problem of airway and breathing. Swollen lips and swollen eyes show signs of angioedema that does not rule out the possibility that it can also occur in the respiratory tract. Although the patient did not complain of tightness, the patient had tachypnea (with a respiratory rate of 24 times/minute) and the patient's saturation showed 94\%. After the treatment with oxygen and corticosteroid drugs in the form of injection of methylprednisolone dose $375 \mathrm{mg}$, the patient was evaluated and the development of the condition indicated by changes in the respiratory rate to 20 times/minute and oxygen saturation to $98 \%$. In severe cases where acute upper respiratory problems occur, airway relief measures such as laryngoscopy and administration of high-dose injection steroids such as methylprednisolone 1000 mg can be considered according to the patient's condition ${ }^{19}$. Patients can also be considered to be taken into the Intensive Care Unit (ICU) if they have severe complications.

The establishment of diagnosis and etiology of angioedema was done after the patient's emergency condition has passed and the patient was considered stable. The diagnosis of SLE is based on The American Rheumatism Association Revised Criteria for Classification of Lupus. In
Indonesia, the Indonesian Rheumatology Association also suggests the use of this diagnostic criteria9 9 . Some diagnostic criteria can be established based on history and physical examination, other diagnostic criteria require supporting examinations. This classification consists of 11 criteria where the diagnosis must meet 4 of the 11 criteria that occur simultaneously or with a grace period.

The establishment of the etiology of angioedema with suspicion of non-allergic causes can be done after examination of C1-INH measurements and $\mathrm{C}_{4}$ antigens. If both are normal, a diagnosis of angioedema due to C1-INH deficiency can be excluded. If both are low or less than $50 \%$, the diagnosis of angioedema is due to $\mathrm{C}_{1}-\mathrm{INH}$ deficiency can be concurred. If the diagnosis of C1INH deficiency has been established, the next step is to distinguish whether the deficiency is due to AAE or HAE. An examination that can be done to distinguish the two is the C1q examination, in which AEE patients are decreased to $70 \%$ and HAE patients are normal. ${ }^{20}$

If the diagnosis of SLE has been established and the diagnosis of $\mathrm{C}_{1}$ deficiency has also been established, thus the diagnosis of the etiology of angioedema due to SLE can be established and exclude the diagnosis of etiology of allergic angioedema. However, with the condition of the emergency department, some of the examinations are difficult to do. Measurements can be made when the patient is in an inpatient or outpatient installation. Therefore, establishing a diagnosis of SLE with diagnostic criteria is the most appropriate way to direct the suspected etiology of angioedema due to $\mathrm{C}_{1-I N H}$ deficiency.

In reported patients, the diagnosis of SLE is established based on the discovery of malar rash, discoid rash, photosensitivity, and oral ulcers from anamnesis and physical examination. Corticosteroids in the form of methylprednisolone IV is immediately given to relieve patient complaints. After administration of the drug, the patient is observed and planned to be hospitalized. One hour after administration of the drug, the patient's condition gradually improved, seen from the results of examination of the patient's vital signs. Angioedema in patients seen from swollen lips gradually disappears. This might be due to the steroids that make it possible to reduce angioedema caused by non-histaminergic angioedema. ${ }^{21}$ In this case, if the cause is proven to be C1-INH deficiency due to an increase in catabolism caused by SLE, the recommended therapy is Danazol or Stanozol which are synthetic steroid and might work on $\mathrm{C}^{1-\mathrm{INH}} .^{13}$ The use of 
synthetic steroids is an effective therapy in most cases with a minimal profile of side effects ${ }^{22}$. In developed countries, the use of prophylactic therapy is very effective in patients with angioedema due to $\mathrm{C}_{1-I N H}$ deficiency. ${ }^{23}$ In severe emergency cases, $\mathrm{C} 1$ inhibitor concentrate can be used. Other therapeutic options that can be used are frozen plasma and solvent/detergent-treated plasma. ${ }^{24}$ The three therapies are effective and one of them can be used as the preferred therapy. Plasma-derived C1-inhibitor ( $\mathrm{C} 1-\mathrm{INH})$ concentrates currently can also be a prophylactic choice. ${ }^{22}$

After therapy given, further evaluation should be carried out by putting the patient into the inpatient installation. In the inpatient installation, later evaluations of the patient's clinical improvement can be carried out (eg. anemia) and can be planned for specific laboratory examinations to support enforcement of other diagnostic criteria such as Anti-DNA; Anti-Sm; anti-phospholipid antibodies; and positive antinuclear antibodies (ANA). Examination of $\mathrm{C}_{1} \mathrm{INH}$ measurement and $\mathrm{C}_{4}$ antigen to establish C1-INH deficiency can be done. ${ }^{17}$

\section{CONCLUSION}

The pathophysiology of angioedema in SLE is based on the mechanism of C1-INH deficiency. Comprehensive management of angioedema treatment in patients with SLE in Emergency Departments in Indonesia can begin from emergency handling, the establishment of SLE diagnosis and etiology of angioedema, management of therapy plan and monitoring at the $E D$, and ends with the management of inpatient or outpatient installations. After the main emergency which is respiratory obstruction has been handled, establishment of the SLE diagnosis can be done. Doctors can do the diagnosis establishment in the emergency department in Indonesia because most of the criteria can be met with anamnesis, physical examination, and supporting examinations available. If the SLE diagnosis has been established and the etiologic edema is proven because of the C1-INH deficiency, the treatment options that can be given is $\mathrm{C}_{1}$ inhibitor concentrate, fresh frozen plasma or solvent/detergent-treated plasma. The patient then remains evaluated by being included in the hospital's inpatient installation

\section{REFERENCES}

1. Manson JJ, Rahman A. Systemic lupus erythematosus. Orphanet $J$ Rare Dis [Internet]. 2006 Dec 27;1(1):6. doi: 10.1186/1750-1172-1-6

2. Rosenbaum E, Krebs E, Cohen M, Tiliakos A,
Derk C. The spectrum of clinical manifestations, outcome and treatment of pericardial tamponade in patients with systemic lupus erythematosus: a retrospective study and literature review. Lupus. 2009 Jun 11;18(7):60812. doi: $10.1177 / 0961203308100659$

3. Jakes RW, Bae S-C, Louthrenoo W, Mok C-C, Navarra S V., Kwon N. Systematic review of the epidemiology of systemic lupus erythematosus in the Asia-Pacific region: Prevalence, incidence, clinical features, and mortality. Arthritis Care Res (Hoboken). 2012 Feb;64(2):159-68. doi: 10.1002/acr.20683

4. Pusat Data dan Informasi KKRI. Situasi Lupus di Indonesia. Infodatin. 2017; https://pusdatin.kemkes.go.id/folder/view/01/str ucture-publikasi-pusdatin-info-datin.html

5. Urowitz MB, Gladman D, Ibañez D, Bae SC, Sanchez-Guerrero J, Gordon C, et al. Atherosclerotic vascular events in a multinational inception cohort of systemic lupus erythematosus. Arthritis Care Res (Hoboken). 2010 Jun;62(6):881-7. doi: 10.1002/acr.20122

6. Fernandes N, Gomes G, Capela C. Presentation of systemic lupus erythematosus (SLE) in emergency department: a case report. BMC Res Notes. 2013;6(1):181. doi: 10.1186/1756-0500-6-181

7. Garris C, Shah M, Farrelly E. The prevalence and burden of systemic lupus erythematosus in a medicare population: retrospective analysis of medicare claims. Cost Eff Resour Alloc. 2015 Dec 6;13(1):9. doi: 10.1186/s12962-015-0034-z

8. Jacobsen, J Petersen, S Ullman, P J S. Mortality and Causes of Death of 513 Danish Patients with Systemic Lupus Erythematosus. Scand J Rheumatol. 1999 Jan 12;28(2):75-80. doi: $10.1080 / 030097499442522$

9. Association of Indonesian Rheumatology. Rekomendasi Perhimpunan Reumatologi Indonesia Untuk Diagnosis dan Pengelolaan Lupus Eritematosus Sistemik. Jakarta: Perhimpunan Rheumatologi Indonesia; 2011.

10. Habibagahi Z, Ruzbeh J, Yarmohammadi V, Kamali M, Rastegar MH. Refractory Angioedema in a Patient with Systemic Lupus Erythematosus. Iran J Med Sci. 2015 Jul;40(4):372-5.

11. Tekin ZE, Yener GO, Yüksel S. Acquired angioedema in juvenile systemic lupus erythematosus: case-based review. Rheumatol Int. 2018 Aug 27;38(8):1577-84. doi: 10.1007/so0296-018-4088-z

12. LoVerde D, Files DC, Krishnaswamy G. Angioedema. Crit Care Med. 2017 Apr;45(4):72535. doi: 10.1097/CCM.0000000000002281

13. Lahiri M, Lim AYN. Angioedema and systemic lupus erythematosus--a complementary 
association? Ann Acad Med Singapore. 2007 Feb;36(2):142-5.

14. Ali SI, Qayser Y, Roohi R. Subtle angioedema presented systemic lupus erythematosus: A case report. Int J Case Reports Images [Internet]. 2013;4(11):631. doi: 10.5348/ijcri-2013-11-397-CR-11

15. Thong BY, Thumboo J, Howe HS, Feng PH. Lifethreatening angioedema in systemic lupus erythematosus. Lupus. $2001 \mathrm{Apr}$ 2;10(4):304-8. doi: 10.1191/096120301680417011

16. Frank MM. Complement disorders and hereditary angioedema. J Allergy Clin Immunol. 2010 Feb;125(2):S262-71. doi: 10.1016/j.jaci.2009.10.063

17. Sonnen AF-P, Henneke P. Structural Biology of the Membrane Attack Complex. In 2014. p. 83116. doi: 10.1007/978-94-017-8881-6_6

18. Tselios K, Urowitz MB. Cardiovascular and Pulmonary Manifestations of Systemic Lupus Erythematosus. Curr Rheumatol Rev. 2017 Dec 26;13(3). doi: 10.2174/1573397113666170704102444

19. Keane MP. Rare diseases bullet 7: Pleuropulmonary manifestations of systemic lupus erythematosus. Thorax. 2000 Feb 1;55(2):159-66. doi: 10.1136/thorax.55.2.159

20.Cicardi M, Zanichelli A. Acquired angioedema. Allergy Asthma Clin Immunol. 2010 Jul 28;6(1):14 doi: 10.1186/1710-1492-6-14

21. Wong BN, Vadas P. Angioedema suppressed by a combination of anti-histamine and leukotriene modifier. Allergy, Asthma Clin Immunol. 2017 Dec 13;13(1):28. doi: 10.1186/s13223-017-0201-1

22. Longhurst H, Zinser E. Prophylactic Therapy for Hereditary Angioedema. Immunol Allergy Clin North Am. 2017;37(3):557-70. doi: 10.1016/j.iac.2017.04.003

23. Tarzi MD, Hickey A, Förster T, Mohammadi M, Longhurst HJ. An evaluation of tests used for the diagnosis and monitoring of $\mathrm{C}_{1}$ inhibitor deficiency: normal serum $\mathrm{C}_{4}$ does not exclude hereditary angio-oedema. Clin Exp Immunol. 2007 Jul 5;149(3):513-6. doi: 10.1111/j.13652249.2007.03438.x

24. Longhurst HJ. Emergency treatment of acute attacks in hereditary angioedema due to $\mathrm{C}_{1}$ inhibitor deficiency: what is the evidence? Int $J$ Clin Pract. 2005 May;59(5):594-9. doi: 10.1111/j.1742-1241.2005.00352.x 